\title{
The Subjects’ Discursive Practices in Environmental Sciences at the Scientific Context of the University of Southwestern Bahia, Brazil
}

\author{
Silva Thiago Souza ${ }^{1}$, Cestari Luiz Artur dos Santos ${ }^{2, *}$ \\ ${ }^{1}$ Graduate Program on Environmental Science of UESB, Itapetinga, Brazil, CAPES/BRAZIL \\ ${ }^{2}$ Department of Philosophy and Human Sciences, University of Southwestern Bahia (UESB), Vitória da Conquista-BA, Brazil \\ *Corresponding author: thiago_uesb@yahoo.com.br; lacestari@hotmail.com
}

\begin{abstract}
The advent of modernity and its conception of knowledge demanded a strong specialization, an intention of universalization and the neutrality of subject and object in a self-centered process of methodological constructions. This process was on the base of the modern sciences since its emergence during the seventeen century until the nineteen century. This model of science has received critical positions since the second middle of nineteen century but it was questioned as a paradigm in crisis at the second middle of twentieth century when the debate about the crisis of the modernity has opened theory conditions to talk about the emergence of interdisciplinary subjects and other paradigms to understand it. One example of it was the emergence of environmental phenomena. After the impact of the Second World War, the environmental sciences as an interdisciplinary approach arise and will propose an effective communication among knowledge in order to offer a more complex perspective since its emergence in the global context. Nevertheless, the legitimization of the new perspective has not become effective because the power relations and the scientific actions on institutions - mainly in universities - have received interference of their disciplinary powers in which is predominant a modern scientifically perspective. This paper aims at discuss the emergence of environmental phenomena and its institutionalization process at the State University of Southwestern Bahia, understanding the scientific actions of researchers and professors as discursive practices in accord with Michel Foucault theory framework.
\end{abstract}

Keywords: subjects, discursive practices, environmental sciences

Cite This Article: Silva Thiago Souza, and Cestari Luiz Artur dos Santos, “The Subjects' Discursive Practices in Environmental Sciences at the Scientific Context of the University of Southwestern Bahia, Brazil.” American Journal of Educational Research, vol. 5, no. 7 (2017): 788-793. doi: 10.12691/education-5-7-15.

\section{Introduction}

During the modernity since its emergence in the seventeen century until the nineteen century, the predominant scientific discourse arise as a method based on a scientific rationality whose more important procedures were the rigor of measurements and reduction of complexity. The areas of knowledge began to work in isolated like islands, making methodologies a restricted place where they supported a single idea of scientific truth. Since then, the scientific areas transformed themselves in disciplines (Gallo [10], Japiassu [12]).

However, the influence of the globalization progress at the second middle of twentieth century and the emergence of the more integrated problems and subjects coming from the social, economic and environmental processes have became urgent the deconstruction of the segregation of these areas (Lyotard [18]). The interdisciplinary approach emerges as a viable proposal to solve the environmental problems such as the problems like soil, water resources, atmospheric, oil crisis, solid waste management, use of pesticides, population growth and so forth.
The interdisciplinary approach debate arose in the 1960 's in academic centers over the world, suggesting an effective communication between the different kinds of knowledge and a comprehensive interaction among fields. It annihilated the egocentric convictions of researchers who had fear of the difference and no interest to break their research method conception as the only one that was able to answer their scientific questions (Morin [20,21,22,23]).

The interdisciplinary approach gave to the sciences a more expanded perspective that had a more potentiality to understand the complexity of nature. How about environmental problems, the interdisciplinarity demanded a more all-embracing range of social and natural knowledge (Leff $[13,14,15,16,17])$, resulting of it a more innovative organization because two or more areas of knowledge should be connected to build a new knowledge.

In Brazilian universities, there is a significant immaturity refers to the interdisciplinary dialogue about environmental problems in learning, research process and extension services. The environmentalization of institutional practices faces an incipient subjects' awareness to break the disciplinary approach due to the conveniences and comforts of the establishment as well as the absence of the public scientific incentives to reach interdisciplinary results. 
This article aims to describe the subjects' discursive practices at the construction and consolidation of environmental sciences in the academic context of the University of Southwestern Bahia (UESB). Based on the concepts from Michel Foucault's theory framework, it has studied the subjects of discourse (professors and researchers) in institutional practices, pointing out the environmentalization process. For this reason, it has introduced the following questions: Which are the discursive regimes making part of environment researchers' and professors' practices? Are the practices providing a more solid and integrated formation? Are the practices advancing forward to the interdisciplinary?

\section{Theory Framework}

It has take a decision to understand the subjects' practices as discursive practices in accordance with the most import Michel Foucault's working, "The archeology of knowledge”. In Foucault's argument, the concept of episteme refers to the well-ordered 'unconscious' structures that are underlain by the production of scientific knowledge in a given time and place, i. e., conditions of possibility for knowledge and cultural thinking. He affirmed the episteme organizes the rules of scientific discourses that are the most based principals of a science, interfering in way of speaking and scientific practices [9].

The discourse and practice are inseparable in Foucault's sense. According to him, the discourse is practice because there is no a dichotomy between thinking and act [2]. Therefore, one important contribution to this working is the understanding of that the subjects' discursive practices (professors and researchers on environmental science, for example) are facing the process of environmental institutionalization in graduate courses at universities, given attention to the positive regimes based on "regimes of truth" that is a historically specific mechanisms which produce discourses as true in particular times and places.

Foucault points out: "For, even with the sixth century Greek poets, true discourse - in the meaningful sense inspiring respect and terror, to which all were obliged to submit, because it held sway over all and was pronounced by men who spoke as of right, according to ritual, meted out justice and attributed to each his rightful share; it prophesied the future, not merely announcing what was going to occur, but contributing to its actual event, carrying men along with it and thus weaving itself into the fabric of fate [3]. And yet, a century later, the highest truth no longer resided in what discourse was, nor in what it did: it lay in what was said. The day dawned when truth moved over from the ritualised act -potent and just of enunciation to settle on what was enunciated itself: its meaning, its form, its object and its relation to what it referred to".

Foucault in your text "The order of discourse" talks about the discursive production and say that it is submitted to a process of control, selection, systematization and dissemination in social context, i. e., many statements and debates are denied in many social groups, such as: "We are aware that we have no the right to say what we want, we can not talk everything in any circumstance, and, finally, anyone can not talk about everything” (Foucault [3]).
In accord with Foucault's sense, there are some forms of suppression in discourses, and he take as an example the interdiction, desegregation and refutation. At the first, Foucault affirmed the discourse is made by three conditions: taboo of the object, ritual of circumstance and privileged right, like he said: "Taboo of the object, ritual of circumstance, privileged or exclusive right of the subject who are speaking: a play of three types of interdicts that intersect, that reinforce or that compensate, forming a complex grid that is always changing” (Foucault [3]).

This typology of discursive regulation will find better examples in the context of politics and sexuality in which discourse is more controlled. It is often observed that speech loses its transparency and neutrality to become the space where the word exerts power and privilege, especially in these areas (Foucault [7]). In both processes of separation or rejection, he discusses the divergent interaction between reason and madness. And, from this it intends to demonstrate what the value of truth is located within the discourse to say who is normal or crazy (Foucault [5]).

Foucault employs the Greek concept of truth who considered that the true discourse was pronounced by those who had the right to do so, and in accordance with the requested ritual. Otherwise, there must be a legitimization, as well as an environment and an adequate situation so that the word stated is true. The madman understood as the one who does not possess intelligible mental faculties and is incapable of expressing a true discourse, like it: "Since the arcana of the Middle Ages, the madman is one whose speech can not be transmitted like that of others: either his word is worthless and does not exist, having neither truth nor importance, being unable to testify in matters of justice, and can not authenticate an act or a contract” (Foucault [3]).

After the Renaissance period, the conception of truth abandons its ritualistic nature and was seen as an established relationship between meaning, object and reference. This means that all truth judgment is assimilated into the discourse itself, not into its externality. Foucault argues that truth will always be used as a methodology to dominate and govern society.

To sum up, Foucault [3] says that all discourse is composed of selective actions (subjects' discursive practices) that communicate a demarcation, a consent, the repression of social behaviors, and establishes what should be accepted or rejected, as well as prescribes the actions that must be characterized as dependent on the historical-cultural situation. It is also necessary to consider the factor of social empowerment in which one has in view the "...political way of maintaining or modifying the appropriation of discourses with the knowledge and the powers they bring with them" (Foucault [3]).

With this in mind, this research refers to an emblematic condition in environmental science that is the irrefutable statement of this field as interdisciplinary. It must be accept one of theory conditions of recent times that has expressed by the failure of the isolation of knowledge and its blind specialization to answer questions on contemporaneous age, while we are facing the contrary: the approaching of fields, knowledges, process, technologies in order to form new groups of interest. 
Then, the emergence of environmental science became possible because it has pointed out the problem of epistemological rupture between human and nature, as well as has fought to overcome this rupture that has brought to the new researchers and professors an image of science guided for two different forms of legitimization or subjects' discursive practices: the pragmatics of scientific knowledge and the narrative knowledge (Foucault [18]).

The interdisciplinarity result of it, when two or more forms to construct knowledge assumes theory and methodology exchanges, constructs new concepts and accepts an increase grade of inter-subjectivity in attempt to answer the multiple and complex nature of phenomenons. Interdisciplinarity involves the convergence of two or more areas of knowledge that do not make part of the same types and contributes to advance of technology and scientific boundaries, that will transfer methods from one to other area creating new knowledge and disciplines. Moreover, a new and distinct professional profile of researchers arises with basic, solid and integrative formation.

Therefore, environmental sciences is seen as a domain that results at same time of the convergence of researchers' interest about the environment as well as regarding the contemporaneous demands to construct an epistemology based on the claim of the suture between human and nature.

\section{Methodology}

\subsection{Discursive Production}

This research will be followed the methodological process in accord with Fischer [1] whose papers about discursive production are based on the Michel Foucault's theory framework. On this research, the oral sentence and the discourses are places of incessant clashes where the discursive and non-discursive practices must be observed.

The discourse must be considered as a dimension of confluences and it implies overcoming the logic that it has a content that express only a system of signs. However, it should be interpreted as practices that systematically provide the elements that are enunciated (Foulcault [6]). In accord with Foucault, there is a complex integration between words and things because the historical aspects make parts of a number of interpretations and power relations (Foucault $[4,8]$ ). Before that, it is important to show how the discourses were dissipated and transformed in a policy of truth (Gregolin [11]).

On this way, this paper had paid attention to the conditions to establish some statements and situations of their effects in order to outline how some discourses about environmental problems will appear and others are restrained and even rejected in a certain contexts and places.

\subsection{Interview with the Subjects of Discourse}

Professors and researchers (subjects of discourse) was interviewed about environmentalization of institutional practices using a qualitative approach and introducing important questions themes to explore during the interview. It used an open perspective to accept emergent subjects and problems suggesting by interviewed, as well as the interviews were saved and after transcribed in papers to be submitted in an analysis using the methodological procedure of analysis textual discursive to organize and produce statements that are dispersed at the text (Moraes; Galiazzi, [19]).

This process begins with fragmentation of the texts that will be reorganized in categories related to the objective of this research. After that, it will describe the subjects' discursive practices based on statements collected during the interviews.

The interviews were conducted with professors and researchers that teach and research environmental themes in attempt to study how they have conduct researches and how the themes have circulated and institutionalized in practices inside UESB and in relation to other institutions, mainly in institutions to support researches.

On this research, these subjects produce discursive practices about environmental themes before requirements of complexity and multiple perspective. Thereby, this study aims to understand the power micro-relations process established in institutional practices and its influences that came from the policies of State, institutions to support grants and the evaluations process of peer-reviewed.

For data collection was used a road-map for interviews composed by questions in which were explored information about the subjects' academic formation, what they understanding about environmental sciences, which adaptive process their projects have submitted to get financial supports, how is the interaction among others researchers and fields to construct the environmental knowledge, and what is the theory and methodological framework of their practices of research.

\subsection{Research Results}

The interviewed A affirmed that The Graduate Program on Environmental Research at UESB received advising to establish the master's degree in an interdisciplinary approach and it had made part of the Interdisciplinary Area of the CAPES/BRAZIL (Higher Level Personnel Improvement Coordination), highlighting the good results of it to the scientific practices. However, during of the course and before the first evaluation in four years the Program migrated to a specific area of Environmental Science that embraced multidisciplinary courses but they did not have the same demand to construct an interdisciplinary perspective in their researches.

Then, despite researchers take in consideration the multilateralism of fields, they still perform researches in disciplinary approach, like it can note in the following quote: "When the master' degree began, an adviser from São Paulo ABC University came here and talked about the importance of the interdisciplinary approach and how we could do it. So, everybody created disciplines thinking about it. All at once, the course changed the approach from Interdisciplinary to Environmental Sciences, and although it has happened, we did not let to work in an interdisciplinary approach. I think that a course in Environmental Area is more important to attend the CAPES'demands, however, in order to do our work I think that an interdisciplinary approach is more useful in our reality" (Interviewed A).

When I put in question the grants to support researches, the Interviewed $\mathrm{B}$ believed that when researchers use the 
word "environment" the proposals have more chances to be approved because it has been a priority theme for the government. However, he said that on the behalf of environment debate there is something that is more determinant to approve one proposal that is the quantity and frequency of published papers.

Same perception it has found in Interviewed C, when he present as one in many of contributions of environmental researches the genetic manipulation of biological species threatened with extinction. Based on it, he affirmed that researches supported on these justifications have more chances to be approved.

Moreover, the environmental knowledge on these proposals must be immediately or not more applied in a specifically reality, and researchers ought to work hard to show that their researches will produce in a briefly future positive results. It means to say that if the research do not immediately propose to solve problems, it can still be received a good evaluation but will not have the financial support to accomplish it. On this evaluation, applied researches and those who have intention to present interventions in realities have frequently been more accepted.

Researchers means it with a capitalist systemic answer and said it is established at the field of research on the following way. Financial institutions to support researches prescribe their expectations about priority themes and the proposals must be framed within this context because proposals out of them should probably not receive financial supports, like said the interviewed C: "We are in a society that is totally capitalist, then, it will be better who is more convincing and who write the better discourse. Who can not do this is left behind. It is different in genetic area because who is reading the genetic proposals, sometimes can be a researcher from agronomic area, so he want to see research results to plants that have been more resistant or used less insecticides and pesticides. On this way, we can show the economical justification for the proposal. It do not means that happened the same way at the ecology area in which, in general, who will read the proposal do not see the importance of the economical justification. For instance, what is the advantage to investigate a little plant in the forest? Is it given money for whom? So, sometimes working with environment is hard because you must create a justification to valorize the proposal and you must do it because referees need to see the value of research because the research results will consequently not give money, will not diminish transgenic production or will not produce any medicine. The maximum what we can say will be: - if you preserve the biodiversity you are preserving resources and these can bring medical answers to the demands of society in the future. The problem of it is that the impact of the research will be on long time and people want to have immediate results. It is different to say: - oh, I have researched about a plant whose insecticide potential is very active and we can fight against the spreading of the dengue mosquito. On this way, it will rain money to accomplish research even from the United States because people have fear of Zica now. However, if I said: Am I studying an environment in which plants and animals are interchanging or can it help to control the population of natural insects? Who will give money for it?" (Interviewed C)
The Interviewed $\mathrm{C}$ presents an understanding about the environmental knowledge of they are made based on a strong social claim around the events and catastrophic phenomenons that will negatively affect the society in great proportions. What is highlighted on this, the State encourages environmental researches based on policy of fear and have transferred to the researchers the accountability to present effective solutions to emergent problems. The emphasis of researches is on the biological partial that affect the human in a specific point, and they have less and less studies about social situations in environment sciences, for example, studies about how we can educate individuals to establish a harmonic relation within environment.

The impact of Aedes Aegypti, for instance, is, therefore, an emergent theme to justify the research and approve a grant, given attention to the effect of discourse about a claim of a social event that has an impact in a perception of the society. It means to say that the justifications of researches must embrace an argument about the correct interference in reality and how they can minimize its impact in society.

On the other hand, researchers considers as a less value the shift of the human behavior that will provide the spreading of the vectors in endemic areas, and the commitment of environmental sciences to attend demand presented by the State is the reason to do not concerning about researches in human action over environment. Maybe it can justify the less importance of the human approach to accomplish research in the environmental context because there are few environmental projects on this perspective. In general, financial institutions want to give number results and researches with descriptive methodologies are far away of this intention.

The interviewed D ascribes difficulties to apply and approve their projects in environmental sciences. He understanding that its proposal present a clear distinction between environmental research and agronomic research but he knows that the better justification to obtain grant to support its research must be agronomic arguments because the referees that will evaluate the proposal did not still accept environmental arguments, like he said: "We had difficulties to obtain financial supports when our justification was based on environmental arguments. So, I had to do the double way and I still have to do it now. I have to show the agronomic and economic importance in my proposal if I want to obtain financial support in federal or state institutions, and in order to accomplishes part of my research about environmental, my justification is an agronomic justification” (Interviewed D).

In short, the discourses of researchers have presented, on the one hand, the environmental researches in a disciplinary approach to justify them and approve grants, pointing out arguments from agronomic, genetic, botanic or ecologic areas and accepting demands of financial institutional interest. On the other hand, they take the opportunity to accomplish some part of research about environment, trying to do some parts of researches in an interdisciplinary approach.

There is a relation of extreme caution at the negotiation with financial institutions to support researches and researchers must change its object of study for the credit reasons, money, i. e., the argument is designed in accord 
with what the grants demand and the knowledge is submitted to the capitalist society logic and to the State's interest. Moreover, researches that do not adapt to this logic could transform itself in a disappointed proposal. "For example, if I talk: in my research is important to have a local where I save one biodiversity, so I have to plant it and it has to live forever. What am I going to do with it? Anyone can say! I keep that biodiversity there, I can have that plant a hundred years and I never use it for nothing but it has to live by its importance while natural resources. Now, how I present the proposal to obtain a grant and say: - I need more money to keep my plant live. And they answer: Yes, and what is the justification? I talk: - I do not know. It has only live because it effectively must live like other organism. Do they give me money for it? I think not! On the other hand, if I say that I need to keep live this plant because its production is good for drought and for its resistance to one fungus, the financial support can be approved. This is the question, the debate in defeat of environment is an argument always present in justifications but we must acknowledge it has a few value. In sum, you need give more value to the arguments that will effectively produce some kind of resource to the country. In my area, we give attention for it. - Look: that is a natural resource, came from nature and it can give me money, so, I call it resource. If I work with this natural resource I can obtain money to do my work but if I only work with nature probably I can not obtain financial support. It is the same research but the argument change in accord with the financial support”.

\subsection{Discussions}

The collected data showed the intention of Brazilian State through CAPES/BRAZIL in provide an evaluation orientated by the integration of areas of knowledge, taking the interdisciplinary approach as an idea to say what is scientific research. However, researchers have take an uncertain position on this situation because they need at same time to attend exigences for an interdisciplinary approach at the behalf of CAPES, faces themselves and their formative experience in disciplinary research area, as well as the incentives of the grants and the specific demands of referees who have evaluated the proposals.

On this situation, the control and regulation of the discourse (Foucault), i. e., what they say in their proposals, specifically in justifications, what is the expertise area of the referees and the priorities writing in purposes for support research grants, are the context to produce a 'regime of truth' (Foucault) that will select the more important words to make part of it. The contradictions presented by the interviewed during the research express the conflict scene where they will regulate the discourse in accord with the power position of them to say what is truth to the proposals in relation to configuration of people inside the position that they take in that moment.

For this reason, some situations seems like ambiguous at the shared interests. On the behalf of CAPES/BRAZIL, for instance, it has an interdisciplinary area of research in which many graduate courses are making part, and one of them is on environment; and the courses on this area have the commitment to provide the interdisciplinarity. On the other hand, in the area of environmental sciences there are many disciplinary graduate courses and or even multidisciplinary but they are not commitment with the interdisciplinarity.

This situation brings the same ambiguity to the context of the course on environmental sciences in UESB and the decision to make part of one or other came from the composition of the council of the course as well as from the better power relations in favor to disciplinary or interdisciplinary approach that moment. On this case, the researchers' fear to face a new form to accomplish research in interdisciplinary approach was important to take the decision because they would need to do exchanges, construct new concepts and increase the grade of inter-subjectivity among other researchers.

This ambiguity is not only happening at the role of institutions but it make too part of the relations among the subjects, for example, between interviewed and the referees of support grant research institutions. The adjustment of the justifications of researches in accord with the institutions, areas, and even the possible referee who will read the proposals are playing in the game. Foucault named it social empowerment that is a process of appropriation of the discourses to keep or modify them in accordance with the knowledge or power that they take office, establishing what would be accepted or rejected in terms of research proposal.

Other example of it is about the subjects (researchers) that have worked with profitable biological materials and the environmental justification in their projects have only become a pretext to attend demands that came from public applications on researches.

This practice makes part of the academic formation of researchers that starting at the scientific research initiation in a relation between adviser and advisy, avoiding any discordance to submit a proposal of research, and the process to accept an application is at same time a process of submission of power relations established between universities and institutions to support researches.

The interference of State will be more effective when the regular agencies like CAPES/BRAZIL, for example, demand a great numbers of quantitative publications to the researchers, many hours of working in laboratories whose have sometimes absence of salubrity and the better devices and material to do researches. Despite of it, researchers need to keep their publications if they want to get new grants and applications.

The forms of interference refers to the trend to adjust the ecological discourse in favor to attend the demands of market or even to the problems in which the State need to solve. For instance, researchers have talked about the improvement of biological material in attempt to raise agronomic resistance and consequently the production, as well as there are researches that put in their arguments the objective to help and create public policies like the specific case about studies of dengue presented in research results.

On the other hand, the control is not restrict to research process because their results need to accept and publish in journals of worldwide circulation and impact. One of difficulties facing for the interviewed that moment is that many journals with high impact in Brazilian evaluation of journals (Qualis) is classified in a disciplinary approach while on the program of environmental science the researches would have been developed in an interdisciplinary 
perspective. However, they plays a double role in a practice of research because present their justification in terms of environmental discourses but do not achieve their researches on an interdisciplinary approach.

As well as, many journals are not specific journals to publish researches about environment and they affirmed that doing research on environment but do not send their papers to journals about environment, keeping this double role in their practices, that is, a kind of adaptation in which they must to attend the demand from external conditions of researches.

Hence, the subjects' discursive practices are presented as places at the relations of powers in which researchers and professors are taking a position that represents their better relations in the game. The research results have shown that doing science is making part of this game, and must be out of the game who does not want to attend the rules and submitted to the conditions of State, Market or other researchers. Lyotard [15] can explain it better and seems like well adequate to this situation: the UESB at he context of these practices have difficult to go beyond an education and research that reproduces the performativity of the system.

\section{Conclusions}

This work has shown that doing science is to make part of power relations among subjects in an institutional environment and it means taking place in their discursive practices. For this reason, the environmentalization process at the universities has take part of this same game because the process embraces the practices to establish how the knowledge is distributed, controlled and disseminated in the subjects' discursive practices. The role of the CAPES/BRAZIL, for instance, to accept disciplinary and interdisciplinary courses has been important to keep in institutions the same ambiguity.

Consequently, the subjects' discursive practices have been places of contradictions because researchers must take positions and decide in favor of the better relations and discourses that they are obliged accepting. A position that is well common has been the heteronomy of researchers because they need to do accords in all moments of their researches. If they want to approve grants, they need to do the play of justification, using or not a discourse in favor of environment, who is my reviewer and in which journals I must submit the articles, so on so thurth.

Therefore, there are so many accords that the interdisciplinary will be or not a discourse to put in action in accord with situation, i. e., if I get good results the word must be included but if not, it is not better talk about it.

Hence, the subjects' discursive practices means at same time the ambiguity of situations and the heteronomy of researchers, using the discourses in favor of the environment and or the interdisciplinary when they can offer advantages at the game of power relations to obtain financial supports or approve grants. Moreover, two more results it has achieved: the practices are not enough to advance forward to a more integrated formation of researches and to consolidate interdisciplinary research practices such as it demands the enviromentalization process in institutions.

\section{References}

[1] Fischer, R. M. B. Foucault revoluciona a pesquisa em educação? Perspectiva, Florianópolis, v. 21, n. 02, p. 371-389, jul./dez., 2003.

[2] Fonseca, M. A. Michel Foucault e a constituição do sujeito. São Paulo: Educ, 2003

[3] Foucault, Michel. The Archeology of knowledge and the discourse on language. Translated from the French by A. M. Sheridan Smith, Pantheon Books, New York, 1972.

[4] Foucault, M. O sujeito e o poder. In: DREYFUS, H. \& RABINOW, P. Michel Foucault. Uma trajetória filosófica: para além do estruturalismo e da hermenêutica. Rio de Janeiro: Forense Universitária, 1995. p. 231-249.

[5] Foucault, M. História da loucura: na idade clássica. 8. ed. São Paulo: Perspectiva, 2009.

[6] Foucault, Michel. The Archeology of knowledge and the discourse on language. Translated from the French by A. M. Sheridan Smith, Pantheon Books, New York, 1972.

[7] Foucault. M. Ética, sexualidade, política. Organização e seleção de textos Manoel Barros da Motta. Rio de Janeiro: Forense Universitária, 2004.

[8] Foucault, M. Microfísica do poder. 23. ed. São Paulo: Graal, 2004b.

[9] Fuente, L., MESSINA, L. La arqueología como método em Michel Foucault. In: Revista Litorales. Ano 2, n², agosto de 2003.

[10] Gallo, S. Transversalidade e educação: pensando uma educação não disciplinar. In: ALVES, N. \& LEITE, R. O sentido da escola. Rio de Janeiro: DP\&A, 2000.

[11] Gregolin, M. R. Foucault e Pêcheux na análise do discurso: diálogos e duelos. São Carlos: Claraluz, 2007.

[12] Japiassú, H. Interdisciplinaridade e Patologia do Saber. Rio de Janeiro: Imago, 1976.

[13] Leff, E. Ambiente, interdisciplinariedad y currículum universitário: la educación superior en la perspectiva del desarrolo sustentable. In. ALBA, A. El curriculum universitário: de cara al nuevo milênio. México: Universidad Nacional Autónoma de México, 1997, 205-211 p.

[14] Leff. E. Ecologia, capital e cultura: a territorialização da racionalidade ambiental. São Paulo: Cortez, 2009.

[15] Leff, E. Epistemologia ambiental. 2. ed. São Paulo: Cortez, 2002.

[16] Leff. E. Racionalidade Ambiental: a reapropriação social da natureza. Rio de Janeiro: Civilização Brasileira, 2006.

[17] Leff, E. Saber ambiental: sustentabilidade, racionalidade, complexidade e poder. Petrópolis: Vozes, 2001.

[18] Lyotard, J. F. A condição pós-moderna. Lisboa, Ed. Gradativa, 1983.

[19] Moraes, R.; Galiazzi, M. C. Análise textual discursiva. Ijuí: Ed. Unijuí, 2007.

[20] Morin, E. A religação dos saberes: o desafio do Século XXI. Trad. Flávia Nascimento. Rio de Janeiro: Bertrand Brasil, 2001.

[21] Morin, E. A cabeça bem feita: repensar a reforma, reformar o pensamento. Trad.: Eloá Jacobina. 7. ed. Rio de Janeiro: Bertrand Brasil, 2002.

[22] Morin, E. Le paradigme perdu: la nature humaine. Paris: Éditions du Seuil, 1973.

[23] Morin, E. Ciência com consciência. Rio de Janeiro: Bertrand Brasil, 1999. 